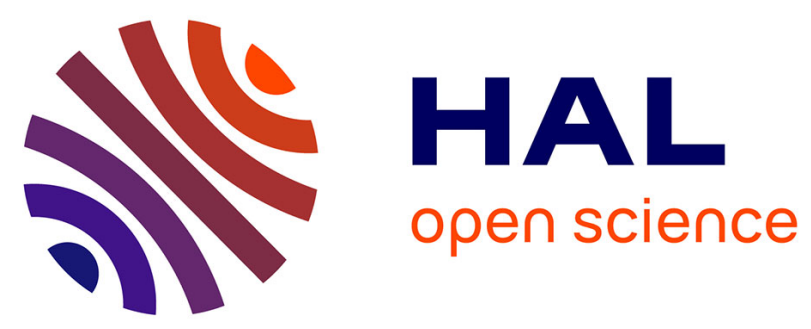

\title{
A new tandem surface analyser
}

K.H. Purser

\section{To cite this version:}

K.H. Purser. A new tandem surface analyser. Revue de Physique Appliquée, 1977, 12 (10), pp.15861586. 10.1051/rphysap:0197700120100158600 . jpa-00244375

\section{HAL Id: jpa-00244375 https://hal.science/jpa-00244375}

Submitted on 1 Jan 1977

HAL is a multi-disciplinary open access archive for the deposit and dissemination of scientific research documents, whether they are published or not. The documents may come from teaching and research institutions in France or abroad, or from public or private research centers.
L'archive ouverte pluridisciplinaire HAL, est destinée au dépôt et à la diffusion de documents scientifiques de niveau recherche, publiés ou non, émanant des établissements d'enseignement et de recherche français ou étrangers, des laboratoires publics ou privés. 


\title{
A NEW TANDEM SURFACE ANALYSER
}

\author{
K. H. PURSER
}

General Ionex Corporation, Ipswich, Massachusetts 01938, U.S.A.

Résumé. - On discute d’un nouveau type d'analyseur de surface basé sur le principe du tandem.

Abstract. - A new surface analyser based on the tandem principle will be discussed.

A new surface analyzer based on the tandem principle will be discussed for applications in the fields of Rutherford backscattering analysis, proton induced $\mathrm{x}$ ray analysis, heavy ion induced $\mathrm{x}$-ray surface analysis, and inverse nuclear reaction analysis. The technology of large accelerators including inclined field tubes, negative helium generator and sputter source technology have been combined to produce this new machine which will be primarily used outside the field of nuclear physics. 